\title{
Cancer and Altered Metabolism: Potential Importance of Hypoxia-Inducible Factor and 2-Oxoglutarate- Dependent Dioxygenases
}

\author{
W.G. KAELIN, JR. \\ Howard Hughes Medical Institute, Dana-Farber Cancer Institute and Brigham and Women's Hospital, \\ Harvard Medical School, Boston, Massachusetts 02215 \\ Correspondence: William_kaelin@dfci.harvard.edu
}

\begin{abstract}
Hypoxia-inducible factor (HIF) deregulation contributes to the Warburg effect. HIF consists of an unstable $\alpha$ subunit and a stable $\beta$ subunit. In the presence of oxygen, HIF $\alpha$ becomes prolyl hydroxylated by members of the EglN (also called PHD) family, leading to its proteasomal degradation. Under hypoxic conditions, EglN activity is diminished and HIF levels rise. EglN1 is the primary HIF prolyl hydroxylase with EglN2 and EglN3 playing compensatory roles under certain conditions. EgIN2 and EglN3 also appear to play HIF-independent roles in regulating cell proliferation and apoptosis, respectively. The EglNs belong to a large family of 2-oxoglutarate-dependent dioxygenases that includes the TET DNA hydroxymethylases and JmjC-containing histone demethylases. Members of this superfamily can be inhibited by endogenous metabolites, including fumarate and succinate, which accumulate in tumors that have fumarate hydratase (FH) or succinate dehydrogenase (SDH) mutations, respectively, as well as by the 2-hydroxyglutarate detected in isocitrate dehydrogenase (IDH) mutant tumors. 2-Oxoglutarate-dependent dioxygenases therefore provide a link between altered metabolism and cancer.
\end{abstract}

Otto Warburg noted decades ago that cancer cells maintain very high rates of glycolysis, converting glucose to lactate, despite sufficient oxygen to perform oxidative phosphorylation, which is the more efficient means of generating energy (ATP) from glucose. This conundrum has generated considerable speculation as to whether altered metabolism, including altered glucose metabolism, is a cause or consequence of malignancy and, if the former, what benefits altered metabolism might confer on cancer cells. Several lines of evidence, including the recent identification of mutations affecting fumarate hydratase $(\mathrm{FH})$, succinate dehydrogenase $(\mathrm{SDH})$, and isocitrate dehydrogenase (IDH), have strengthened the notion that altered metabolism can cause cancer, and a number of nonmutually exclusive models have been put forth to rationalize why cancer cells might benefit from a high rate of glycolysis and decreased oxidative phosphorylation. This chapter focuses on the role of hypoxia-inducible factor (HIF), 2-oxoglutarate, and 2-oxoglutarate-dependent enzymes in cancer and cancer metabolism.

\section{THE HIF TRANSCRIPTION FACTOR}

When cells are placed in a low-oxygen environment, they normally undergo a series of metabolic adaptations, including an increase in glucose uptake and glycolysis and a decrease in oxidative phosphorylation. Conversely, the presence of oxygen is associated with a decrease in glycolysis and an increase in oxidative phosphorylation. The coupling of oxidative phosphorylation to oxygen availability is known as the Pasteur effect and is mediated by the HIF transcription factor (Seagroves et al. 2001).
HIF is a heterodimer consisting of an unstable $\alpha$ subunit and a stable $\beta$ subunit (also frequently called ARNT; Kaelin and Ratcliffe 2008). Under low-oxygen conditions, the HIF $\alpha$ subunit is stabilized, dimerizes with a HIF $\beta$ subunit, translocates to the nucleus, and transcriptionally activates a suite of genes that increase glucose uptake, increase glycolysis, and decrease oxidative phosphorylation. The latter is mediated by an increase in PDK (pyruvate dehydrogenase kinase), which phosphorylates, and thereby inactivates, pyruvate dehydrogenase (Kim et al. 2006a; Papandreou et al. 2006). This limits the entry of pyruvate into the Krebs cycle. Instead, pyruvate is converted lactate and extruded from the cell by the HIF-responsive gene products lactate dehydrogenase A and monocarboxylate transporter 4, respectively (Ebert and Bunn 1998; Ullah et al. 2006; Perez de Heredia et al. 2010).

The stability of HIF $\alpha$ is linked to oxygen availability because it is a substrate for the EgIN (also called PHD) family of prolyl hydroxylases (Kaelin and Ratcliffe 2008). In the presence of oxygen, EglN hydroxylates HIF $\alpha$ on one (or both) of two conserved prolyl residues. Hydroxylation of either site creates a binding site for a ubiquitin ligase that contains the pVHL tumor suppressor protein. This complex then polyubiquitinates $\mathrm{HIF} \alpha$, thereby targeting it for destruction by the proteasome. There are three EglN family members. EglN1 appears to be the primary HIF prolyl hydroxylase, with EglN2 and EglN3 playing compensatory roles under certain conditions (Berra et al. 2003; Appelhoff et al. 2004; Marxsen et al. 2004; Stiehl et al. 2006; Minamishima et al. 2009). The oxygen $K_{\mathrm{m}}$ values for the hydroxylation of HIF $\alpha$ by 
EglN family members are slightly above the oxygen concentrations likely to be encountered in tissues under normal conditions (Hirsila et al. 2003). Accordingly, the EglN family members are sensitive to further decrements in oxygen availability (hypoxia), leading to reduced hydroxylation of HIF $\alpha$ and therefore higher steady-state levels of HIF $\alpha$. In addition to oxygen, EgIN family members also require reduced iron and 2-oxoglutarate (also called $\alpha$-ketoglutarate) and their activity can be influenced by reactive oxygen species (ROS) and changes in specific Krebs cycle intermediates (Fig. 1; see also below; Kaelin 2005; Kaelin and Ratcliffe 2008).

\section{THE WARBURG EFFECT}

The Warburg effect is due, at least in part, to the failure of cancer cells to appropriately down-regulate HIF under well-oxygenated conditions because of mutations that either increase HIF production or decrease HIF destruction (Fig. 2). With respect to increased HIF $\alpha$ production, mutations that directly or indirectly inactivate the tuberosis sclerosis complex (TSC), such as activating mutations of PI3K or AKT, lead to increased TORC1 activity (Brugarolas and Kaelin 2004). Increased TORC1, in turn, promotes HIF $\alpha$ transcription and translation (Hudson et al. 2002; Arsham et al. 2003; Brugarolas et al. 2003; Fig. 2). With respect to decreased HIF $\alpha$ destruction, inactivating mutations of the $V H L$ tumor suppressor gene lead to impaired HIF $\alpha$ proteasomal degradation for the reasons outlined above (Fig. 2). Similarly, inactivating $\mathrm{SDH}$ and $\mathrm{FH}$ mutations lead to the accumulation of succinate and fumarate, respectively, which inhibit EglN activity by competing with 2-oxoglutarate, thereby allowing HIF $\alpha$ to escape recognition by pVHL (Fig. 1; Dahia et al. 2005; Pollard et al. 2005; Selak et al. 2005, 2006; Koivunen et al. 2007; Pollard et al. 2007; Kaelin 2009; Sudarshan et al. 2009). A recent study suggested that IDH mutations reduce 2-oxoglutarate production and hence EgIN activity, leading to HIF $\alpha$ stabilization, although this finding has been disputed (Zhao et al. 2009). More recent studies indicate that cancer-relevant

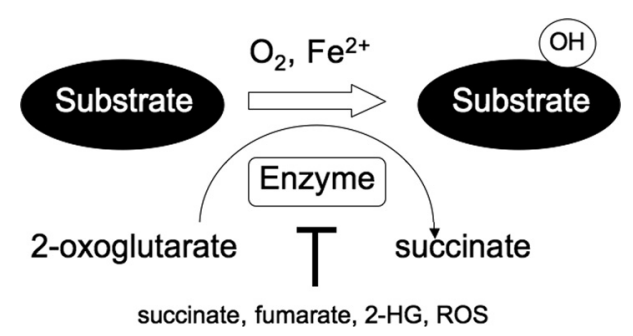

Figure 1. 2-Oxoglutarate-dependent dioxygenase reaction. 2Oxoglutarate-dependent enzymes require 2-oxoglutarate (also called $\alpha$ ketoglutarate), oxygen, and reduced iron to hydroxylate their substrates. 2-Oxoglutarate is decarboxylated to succinate during the reaction. In the case of histone demethylases, a methyl group is hydroxylated and the resulting hydroxymethyl group is spontaneously given off as formaldehyde. These enzymes are variably susceptible to inhibition by Krebs cycle intermediates such as succinate and fumarate, to 2-hydroxyglutarate, and to reactive oxygen species (ROS).
IDH mutants acquire the neomorphic ability to produce R-2-hydroxyglutarate (R-2HC) but R-2HG does not appear to inhibit EgIN activity in cells (Dang et al. 2009b; Chowdhury et al. 2011; P Koivunen, S Lee, and WG Kadin, unpubl.).

Although HIF contributes to the Warburg effect, it does not act alone. For example, many of the effects of HIF on cell metabolism are reinforced by other molecular perturbations in cancer cells, including those leading to activation of c-Myc or loss of p53 (Matoba et al. 2006; Yeung et al. 2008; Feng and Levine 2010; Kaelin and Thompson 2010). Indeed, HIF and c-Myc share a number of common targets that promote glycolysis (Dang 2007; Dang et al. 2009a). Cancer cells also frequently express the M2 isoform of PFK (phosphofructokinase) rather than the M1 isoform found in most somatic tissues (Christofk et al. 2008). Expression of the M2 isoform appears to faciliate the diversion of glucose-derived carbons for anabolism (Christofk et al. 2008). c-Myc promotes glutaminolysis, which provides an alternative source of carbon precursors for anabolism as well as for NADPH production in the Krebs cycle (anaplerosis; Dang et al. 2009a; Dang 2010).

The metabolic changes characteristic of the Warburg effect are believed to allow cancer cells to outcompete their neighbors for nutrients and to use those nutrients for anabolic reactions necessary for growth in addition to energy production. Lactate produced by tumors might also alter the microenvironment in a manner that facilitates both growth and invasion. In addition, changes in mitochondrial ROS production and mitochondrial metabolites (including 2-oxoglutarate) might indirectly affect the behavior of multiple enzymes within the cell, including phosphatases and 2-oxoglutarate-dependent enzymes, that control cell growth and survival.

\section{HIF AND CANCER: BYSTANDER OR CULPRIT?}

Intratumoral hypoxia and hence increased HIF levels are very consistently associated with poor patient outcomes (Semenza 2003). At one extreme, this would reflect the ability of HIF itself to promote tumor growth. On the other hand, it is possible that the correlation simply reflects the fact that the most aggressive tumors are the ones most likely to outgrow their blood supplies and hence to develop intratumoral hypoxia. In favor of the former model, HIF activates a number of genes that might, in theory, promote tumor cell growth, invasion, and metastasis. For example, HIF induces autocrine and paracrine cancer cell growth factors such as TGF $\alpha$ and PDGF B, and promotes invasion by transcriptionally up-regulating genes such as $M M P$ and $L O X$ and angiogenesis by up-regulating genes such as $V E G F$ (Semenza 2003). It is therefore understandable that HIF is usually viewed as an oncoprotein. Moreover, deletion of HIF $\alpha$ (or ARNT) has been shown to decrease tumor growth in nude mouse subcutaneous xenograft assays (Maxwell et al. 1997; Ryan et al. 1998). On the other hand, there is evidence that HIF $\alpha$ can act as a tumor suppressor, at 


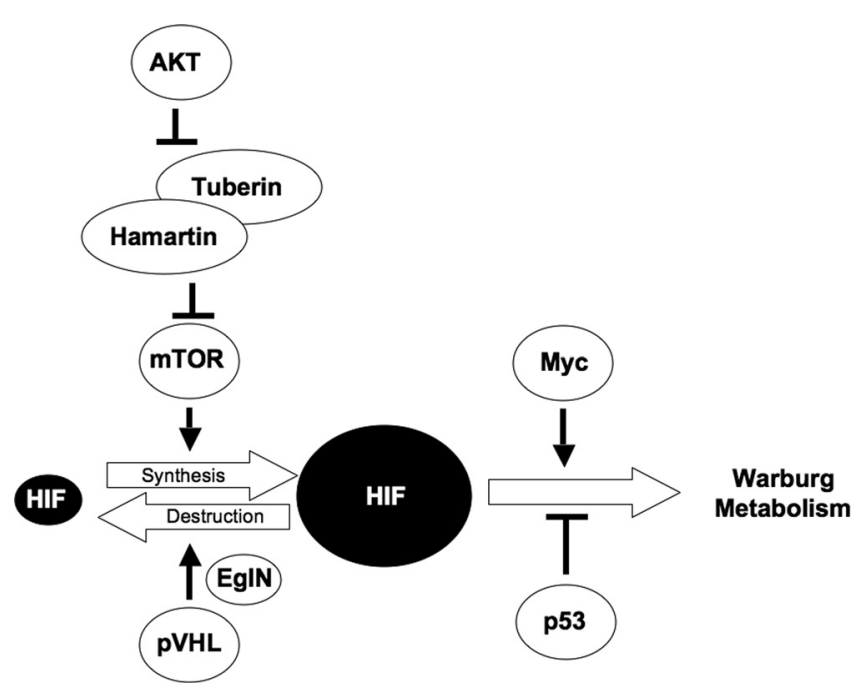

Figure 2. Central role of HIF in Warburg metabolism. Many oncogenic mutations lead to increased HIF accumulation, which promotes the Warburg effect. Increased Myc expression and loss of p53 function can also contribute to such metabolic changes. least in some preclinical models. For example, deletion of HIF $1 \alpha$ promotes the growth of teratocarcinomas formed by embryonic stem cells and orthotopic tumors formed by transformed astrocytes (Carmeliet et al. 1998; Blouw et al. 2003; Covello et al. 2005). Deletion of HIF2 $\alpha$ has been shown to promote the growth of K-Ras-driven lung adenocarcinomas in genetically engineered mice and the growth of astrocytomas (Acker et al. 2005; Mazumdar et al. 2010).

A causal role for HIF $\alpha$ (particularly HIF2 $\alpha$ ) has been perhaps most convincingly demonstrated in pVHLdefective kidney cancers. These tumors produce high levels of both HIF $1 \alpha$ and HIF $2 \alpha$ or, importantly, HIF $2 \alpha$ only (Maxwell et al. 1999; Gordan et al. 2008; Shen et al. 2011). In preclinical models, including orthotopic models, elimination of HIF $2 \alpha$ is sufficient to inhibit pVHL-defective tumor growth (Kondo et al. 2003; Zimmer et al. 2004), whereas restoring HIF2 $\alpha$ (but not HIF $1 \alpha$ ) production is sufficient to override tumor suppression by pVHL (Kondo et al. 2002; Maranchie et al. 2002; Raval et al. 2005). In genetically engineered mice, HIF $2 \alpha$ appears to be necessary and sufficient for much of the pathology observed in tissues that lack pVHL (Kim et al. 2006b; Rankin et al. 2007, 2008, 2009). In patients with germline VHL mutations, the degree to which their VHL alleles are compromised with respect to HIF regulation tracks closely with their risk of kidney cancer (Li et al. 2007) and single-nucleotide HIF2 polymorphisms in the general population have been linked to the risk of kidney cancer (Purdue et al. 2011). Collectively, these results suggest that HIF $2 \alpha$ is a kidney cancer oncoprotein. In stark contrast, HIF $1 \alpha$ appears to behave as a kidney cancer tumor suppressor.

Three signature chromosomal abnormalities in kidney cancer are loss of chromosome $3 \mathrm{p}$, spanning the $V H L$ gene, loss of chromosome 14q, and gain of chromosome 5q. Chromosome 14q loss is most common in kidney cancer relative to other tumor types and almost invariably leads to loss of HIFl $\alpha$ located at $14 \mathrm{q} 22$ (Shen et al.
2011). Many pVHL-defective renal carcinoma lines harbor focal, homozygous, HIF $1 \alpha$ deletions that lead to the production of either no HIF $1 \alpha$ protein or the production of HIF $1 \alpha$ variants that reflect alternative splicing events that circumvent the missing exons (Shen et al. 2011). Restoration of wild-type HIF $1 \alpha$ in such cells suppresses their ability to proliferate in vitro and in vivo (Raval et al. 2005; Shen et al. 2011). Conversely, elimination of wild-type HIF $1 \alpha$ in HIF $1 \alpha$-proficient cells enhances their proliferation in vitro and in vivo (Gordan et al. 2008; Shen et al. 2011). Intragenic HIF $1 \alpha$ mutations have been identified in kidney cancer genome sequencing projects and, when tested, have proven to be loss of function (Morris et al. 2009; Dalgliesh et al. 2010; Shen et al. 2011). Such mutations are, however, rare when compared with the frequency of $14 \mathrm{q}$ loss in kidney cancer. Specifically, many $14 \mathrm{q}$ deleted kidney cancers retain a wild-type $H I F 1 \alpha$ allele (Shen et al. 2011). This suggests that HIF $1 \alpha$ haploinsufficiency contributes to kidney cancer growth. In keeping with this idea, $14 \mathrm{q}$ deleted tumors have a transcriptional signature indicative of HIF $1 \alpha$ loss (Shen et al. 2011).

\section{EgIN PROLYL HYDROXYLASES AS TARGETS OF SDH, FH, AND IDH MUTATIONS}

Deregulation of HIF is also suspected of playing a pathogenic role in papillary renal carcinomas linked to FH deficiency and to paragangliomas linked to SDH deficiency (Gimenez-Roqueplo et al. 2001; Isaacs et al. 2005; Pollard et al. 2005; Selak et al. 2005, 2006; MacKenzie et al. 2007; Pollard et al. 2007; Sudarshan et al. 2009, 2011), although the paucity of relevant cell culture and mouse models has so far prevented the types of preclinical validation experiments described above for pVHLdefective clear cell renal carcinomas to determine whether HIF truly plays a causal, as opposed to correlative, role in these settings. It has also been suggested that SDH mutations lead to paraganglioma in an EgINdependent, but HIF-independent, manner based on the 
following observations. A number of different genes, including $V H L, N F 1, c-$ Ret, and $S D H$ subunit genes, lead to an increased risk of extraadrenal and intradrenal paragangliomas (the latter are called pheochromocytomas), but only when mutated in the germline (Nakamura and Kaelin 2006; Kaelin 2007). This suggests that these genes control a paraganglioma-relevant biologic process that takes place during embryological development. Notably, some germline $V H L$ mutations lead to a high risk of paraganglioma but not kidney cancer or the blood vessel tumors (hemangioblastomas) observed in classical VHL disease (Kaelin 2002). When tested, the products of such mutant VHL alleles are essentially normal with respect to HIF regulation (Clifford et al. 2001; Hoffman et al. 2001). Conversely, VHL mutations that confer a high risk of kidney cancer and low risk of paraganglioma lead to significant deregulation of HIF (Maxwell et al. 1999; Clifford et al. 2001; Hoffman et al. 2001; Li et al. 2007). The simplest interpretation of these findings is that the development of paraganglioma in cells lacking wild-type pVHL reflects the loss of an HIF-independent pVHL function.

Paragangliomas are tumors of the sympathetic nervous system. During embryological development, primitive neuronal cells with the potential to become sympathetic neurons compete for growth factors such as NGF (nerve growth factor), with the losers undergoing apoptosis (Deckwerth and Johnson 1993; Deppmann et al. 2008). NGF withdrawal leads to the induction of EgIN3, which appears to be necessary and sufficient for apoptosis in this setting (Lipscomb et al. 1999; Straub et al. 2003; Lee et al. 2005). Loss of the NF1 gene product neurofibromin, which is a Ras-GAP for the NGF receptor, or gain of c-Ret, which can activate the NGF receptor in cis, leads to decreased apoptosis after NGF withdrawal (Vogel et al. 1995; Dechant 2002; Lee et al. 2005). Paragangliomaassociated $V H L$ mutations lead to activation of aPKC and Jun B, which represses EgIN3 levels (Lee et al. 2005). Finally, SDH mutations lead to the accumulation of succinate, which inhibits EglN3-induced apoptosis (Lee et al. 2005). Hence, all of the genes linked to familial paraganglioma can potentially regulate apoptosis of sympathetic neuronal precursors during embryological development, suggesting that paragangliomas arise in this setting owing to impaired culling of this cell population. The sympathetic nervous system abnormalities observed in $E g l N 3^{-/-}$mice are consistent with this view (Bishop et al. 2008).

EgIN3-induced apoptosis appears to be HIF independent (Schlisio et al. 2008). Interestingly, induction of apoptosis appears, instead, to be linked to its ability to increase expression of $K I F 1 B \beta$, which encodes a kinesin family member (Munirajan et al. 2008; Schlisio et al. 2008). KIF $1 B \beta$ maps to the minimal region of 1 p36 that is deleted in a number of neural-crest-derived tumors, including the sympathetic nervous system tumor neuroblastoma. Loss-of-function $K I F 1 B \beta$ mutations have been identified in a family with neural crest tumors and in a small subset of pheochromocytomas, medulloblastomas, and neuroblastomas (Schlisio et al. 2008; Yeh et al.
2008). The frequency of such mutations is low, however, relative to the frequency of 1 p36 deletions in such tumors. Among several possibilities, this might indicate that haploinsufficiency for KIF1B $\beta$, perhaps together with loss of contiguous genes, is sufficient to promote neural crest tumor development and that complete loss of KIF1B $\beta$ would not.

\section{NON-EgIN TARGETS OF SDH, FH, AND IDH MUTATIONS}

It is also possible that the accumulation of succinate and fumarate observed in SDH and FH mutant tumors, as well as the accumulation of R-2HG in IDH mutant tumors, transforms cells by affecting the behavior of other 2-oxoglutarate-dependent enzymes in addition to (or in some cases, perhaps instead of) the EglN family members (Fig. 1). For example, the jumonji-C domaincontaining histone demethylases are 2-oxoglutaratedependent enzymes (Klose et al. 2006). It is possible that inhibition of one or more of these enzymes, through changes in chromatin structure and gene expression, leads to transformation. In biochemical assays, R-2HG can, with variable potencies, inhibit various histone demethylases (Chowdhury et al. 2011; Xu et al. 2011). The histone demethylase Jhd1, an H3K36 demethylase, is inhibited in a yeast model of SDH deficiency (Smith et al. 2007), as is the H3K27 demethylase KDM6B (JMJD3) in mammalian cells after knockout of SDH with siRNA (small interfering RNA) (Cervera et al. 2009). KDM6B and its paralog KDM6A (UTX) are attractive candidates as targets of succinate, fumarate, and R-2HG because they behave as tumor suppressors in cell culture models by virtue of their ability to increase the expression of the Ink $4 A / A R F$ locus in response to oncogenic stress and to cooperate with the pRB tumor suppressor (Agger et al. 2009; Barradas et al. 2009; Herz et al. 2010; Wang et al. 2010). Moreover, UTX is mutationally inactivated in a variety of tumors (van Haaften et al. 2009; Dalgliesh et al. 2010).

More recently, TET2 has been implicated as a target of R-2HG (Figueroa et al. 2010; Xu et al. 2011). TET2 belongs to a family of 2-oxoglutarate-dependent enzymes that hydroxylate methylcytosine, which is suspected of playing a role in the turnover of methylated DNA (Noushmehr et al. 2010; Ficz et al. 2011). Inactivating TET2 mutations, like IDH mutations, have been observed in acute leukemia, and TET2 and IDH mutations are mutually exclusive, consistent with the notion that IDH mutations lead to TET2 inactivation (and thereby eliminate the selection pressure to mutate TET2; Figueroa et al. 2010). Overexpression of mutant IDH decreases the enzymatic activity of coexpressed TET2 and impairs hematopoietic differentiation (Figueroa et al. 2010; Xu et al. 2011). DNA hypermethylation is also a feature of IDH mutant brain tumors and leukemia, consistent with the idea that IDH mutations impair TET2 activity and thereby impair DNA demethylation (Figueroa et al. 2010; Noushmehr et al. 2010). 


\section{2-OXOGLUTARATE-DEPENDENT DIOXYGENASES AS CANCER THERAPEUTIC TARGETS}

As described above, inactivation of specific 2-oxoglutarate-dependent dioxygenases is suspected of contributing to transformation, especially in the context of $\mathrm{SDH}, \mathrm{FH}$, and IDH mutations. It is also possible that HIF, by limiting the entry of pyruvate into the Krebs cycle, indirectly inhibits such enzymes through changes in Krebs cycle intermediates, although this remains to be proven. At the same time, it is also clear that certain 2-oxoglutarate-dependent enzymes can stimulate, rather than inhibit, cancer cells, at least in certain contexts. In addition, HIF increases the transcription of certain 2oxoglutarate-dependent enzymes (see below), perhaps to compensate for their reduced activity under hypoxia.

It is important to note that different 2-oxoglutaratedependent enzymes can differ substantially with respect to their requirements for oxygen and 2-oxoglutarate $\left(K_{\mathrm{m}}\right.$ values) and sensitivity to inhibition by metabolites such as succinate and $\mathrm{R}-2 \mathrm{HG}$ (IC50 values). As a result, genetic or pharmacological perturbations that affect intracellular oxygen and metabolite levels might affect (indirectly) some enzymes in this family more than others. It has also become clear that members of this family can be directly inhibited with drug-like small molecules that bind to their catalytic sites and interfere with 2-oxoglutarate binding, iron binding, or both (Ivan et al. 2002; Mole et al. 2003; Schlemminger et al. 2003; Safran et al. 2006). Moreover, a number of preclinical studies, described below, support inhibition of specific 2-oxoglutaratedependent dioxygenases having an antitumor effect.

\section{EgIN1}

EglN1 suppresses HIF and would therefore be predicted to be a cell-autonomous tumor suppressor in most (but not all) cellular contexts for the reasons outlined above. Interestingly, however, tumor cell invasion, intravasation, and metastasis are impaired in Egln $1^{+/-}$mice, possibly owing to vessel pseudonormalization and improved intratumoral oxygenation (Mazzone et al. 2009).

\section{EgIN2}

EglN2, a member of the EglN family, is induced by estrogen in estrogen-receptor-positive breast cancers (Seth et al. 2002; Appelhoff et al. 2004; Zhang et al. 2009). Estrogen is an important mitogen for breast cancer cells, simulating progression through the cell cycle. Cyclin D1 promotes cell-cycle progression by directing (together with cdk4 or cdk6) the phosphorylation of the pRB tumor suppressor protein (Sellers and Kaelin 1997). Overexpression and, at times, amplification of cyclin D1 is common in breast cancer (Steeg and Zhou 1998; Roy and Thompson 2006). Notably, certain cyclin D1-dependent phenotypes are lost in flies that lack Egl9, the sole EgIN family member in this organism (Frei and Edgar 2004). Collectively, these observations point to a possible connection between EgIN2 and cyclin D1.
Indeed, loss of EgIN2, but not loss of EgIN1 or EgIN3, decreases the cyclin D1 level in vitro and in vivo. $E g \ln 2^{-/-}$mice are viable but do not breastfeed appropriately, owing to mammary gland hypoproliferation reminiscent of mammary glands that lack cyclin D1 (Zhang et al. 2009). Inactivation of EgIN2 suppresses breast cancer proliferation in vitro and in vivo, owing specifically to loss of cyclin D1 and impaired pRB phosphorylation (Zhang et al. 2009). Loss of EgIN2 also impairs the fitness of a variety of other cancers in addition to breast cancer (Zhang et al. 2009). Control of cyclin D1 by EgIN2 requires EgIN2 catalytic activity but appears to be HIF independent (Zhang et al. 2009). EgIN2 does not hydroxylate cyclin D1 directly (at least under the conditions tested so far) and appears to influence cyclin D1 transcriptionally and postranscriptionally (Zhang et al. 2009).

\section{LOX}

HIF induces the expression of LOX, which encodes a lysyl oxidase. LOX expression by primary tumors appears to play a role in mobilization of bone-marrowderived cells that promote the formation of metastatic niches and hence metastasis (Erler et al. 2006, 2009). LOX has also been implicated in the ability of cancer cells to undergo an epithelial-mesenchymal transition, which is often associated with increased invasiveness and drug resistance (Schietke et al. 2010). It remains to be determined, however, whether inhibition of LOX would cause the regression of established tumors or otherwise favorably alter their natural history.

\section{KDM2A and KDM2B}

KDM2A (JHDM1A or FBX11) and KDM2B (JHDM1B or FBXL10) demethylate H3K36. Loss of KDM2B impairs proliferation and induces senescence, at least partly through an increase in p15/Ink4b or p16/ Ink4a expression (He et al. 2008; Tzatsos et al. 2009). Similarly, depletion of KDM2B in hematopoietic progenitors significantly impairs HOXA9/MEIS1-induced leukemic transformation, at least partly through impaired self-renewal (He et al. 2011). Conversely, KDM2B is the target of a recurrent integration event in a MoMuLV rat lymphoma model and is overexpressed in a subset of leukemia (Pfau et al. 2008; He et al. 2011). Overexpression of KDM2A and/or KDM2B can immortalize mouse embryo fibroblasts and transform hematopoietic progenitors (Pfau et al. 2008; He et al. 2011). Collectively, these observations credit $\mathrm{KDM} 2 \mathrm{~A}$ and $\mathrm{KDM} 2 \mathrm{~B}$ as potential oncogenes.

\section{KDM3A}

KDM3A (JMJD1A, JHDM2A) is an H3K9 demethylase that has been implicated in stem cell maintenance (Ko et al. 2006; Loh et al. 2007). KDM3A is overexpressed in renal carcinoma, presumably because it is the product of an HIF-responsive gene (Beyer et al. 2008; Pollard et al. 2008; Wellmann et al. 2008; Sar et al. 
2009; Xia et al. 2009; Krieg et al. 2010). Down-regulation of KDM3A impairs cancer cell proliferation and invasiveness (Krieg et al. 2010; Yamada et al. 2011).

\section{KDM4B and KDM4C}

KDM4C (JMJD2C, JHDM3, or GASC1) maps to chromosome 9p23-24, which is amplified in esophageal and breast cancers, and demethylates H3K9 (Yang et al. 2000, 2001; Cloos et al. 2006). In keeping with its suspected role as an oncogene, shRNA-mediated knockout of KDM4C inhibits cancer cell proliferation in vitro. Conversely, KDM4C induces transformed phenotypes, including growth-factor-independent proliferation, anchorage-independent growth, and mammosphere forming ability when overexpressed in immortalized, nontransformed mammary epithelial cells (Liu et al. 2009). KDM4C was also recently shown to be coamplified with JAK2 in a subset of lymphomas (Rui et al. 2010). KDM4C cooperates with JAK2 in this setting to regulate chromatin structure and promote lymphomagenesis (Rui et al. 2010). KDM4C might also play a role in androgen receptor signaling in prostate cancer (Wissmann et al. 2007), whereas its paralog KDM4B (JMJD2B) has been implicated in estrogen receptor signaling and the control of breast cancer proliferation (Yang et al. 2010; Kawazu et al. 2011; Shi et al. 2011). Both KDM4B and KDM4C can be induced by hypoxia (Beyer et al. 2008; Xia et al. 2009; Yang et al. 2010).

\section{KDM5A and KDM5B}

KDM5A (also called RBP2 or JARID1A) and KDM5B (also called PLU-1 or JARID1B) are JmjC-containing histone demethylases that recognize methylated H3K4, a mark that is usually associated with transcriptionally active chromatin (Christensen et al. 2007; Hayakawa et al. 2007; Iwase et al. 2007; Klose et al. 2007; Secombe et al. 2007; Yamane et al. 2007). Methylated H3K4 is also found in association with the repressive-mark-methylated H3K27 in so-called bivalent chromatin domains, which are believed to play an important role in stem cell fate determination (Bernstein et al. 2006; Gan et al. 2007; $\mathrm{Ohm}$ et al. 2007). Increased expression of PLU-1 and RBP2 has been linked to an increase in stem-like properties in cancer cells and to drug resistance (Dey et al. 2008; Roesch et al. 2010).

RBP2 was originally identified as a pRB-binding protein and has been linked to control of sensecence and differentiation by pRB (Defeo-Jones et al. 1991; Fattaey et al. 1993; Benevolenskaya et al. 2005). Inactivation of RBP2 impairs the growth of pRB-defective human cancer lines in vitro and in vivo and the development of tumors in $\mathrm{Rbl}^{+/-}$mice (Benevolenskaya et al. 2005; Lin et al. 2011). Similarly, loss of RBP2 impairs the development of tumors driven by loss of the MEN1 tumor suppressor, which is a component of an $\mathrm{H} 3 \mathrm{~K} 4$ methylase complex (Lin et al. 2011). This latter observation suggests that tumors driven by loss of a particular histone methylase might be treated by inhibiting one or more demethylases that normally serve to antagonize its function (or vice versa). This is noteworthy given the frequency with which mutations affecting histone methylases and demethylases are being identified in cancer (Northcott et al. 2009; Dalgliesh et al. 2010; Chapman et al. 2011; Yoshimi and Kurokawa 2011).

PLU-1 is frequently overexpressed in breast cancer, and down-regulation of PLU-1 impairs breast cancer growth in vivo (Barrett et al. 2002; Catchpole et al. 2011). Similarly, PLU-1 is overexpressed in bladder and lung cancer, where its inhibition leads to apoptosis (Hayami et al. 2010). The overexpression of PLU-1 in tumors might be due, at least partly, to its induction by hypoxia (Xia et al. 2009).

\section{SUMMARY}

There are now multiple examples of mutations affecting metabolic enzymes that play a causal role in cancer. Derangements in cellular metabolism can affect oncogenic signaling pathways and vice versa. The HIF transcription factor plays an important role in reprogramming cancer cell metabolism as well as being responsive to changes in cellular metabolism. Recent genetic and biochemical studies related to cancer metabolism point to a potentially important role for 2-oxoglutarate and hence, 2-oxoglutarate-dependent enzymes, in transformation. Pharmacological manipulation of these enzymes might be useful for the treatment of cancer.

\section{ACKNOWLEDGMENTS}

I thank Christine McMahon for careful reading of the manuscript and for fellow laboratory members and colleagues for useful discussions. The research is supported by the National Institutes of Health, Howard Hughes Medical Institute, and Doris Duke Charitable Foundation. I apologize to colleagues whose work was not cited owing to space limitations or my ignorance. Please bring errors and eggregious omissions to my attention.

\section{REFERENCES}

Acker T, Diez-Juan A, Aragones J, Tjwa M, Brusselmans K, Moons L, Fukumura D, Moreno-Murciano MP, Herbert JM, Burger A, et al. 2005. Genetic evidence for a tumor suppressor role of HIF-2 $\alpha$. Cancer Cell 8: 131-141.

Agger K, Cloos PA, Rudkjaer L, Williams K, Andersen G, Christensen J, Helin K. 2009. The H3K27me3 demethylase JMJD3 contributes to the activation of the INK4A-ARF locus in response to oncogene- and stress-induced senescence. Genes Dev 23: 1171-1176.

Appelhoff RJ, Tian YM, Raval RR, Turley H, Harris AL, Pugh CW, Ratcliffe PJ, Gleadle JM. 2004. Differential function of the prolyl hydroxylases PHD1, PHD2, and PHD3 in the regulation of hypoxia-inducible factor. $J$ Biol Chem 279: $38458-38465$.

Arsham AM, Howell JJ, Simon MC. 2003. A novel hypoxiainducible factor-independent hypoxic response regulating mammalian target of rapamycin and its targets. $J$ Biol Chem 278: $29655-29660$. 
Barradas M, Anderton E, Acosta JC, Li S, Banito A, RodriguezNiedenfuhr M, Maertens G, Banck M, Zhou MM, Walsh MJ, et al. 2009. Histone demethylase JMJD3 contributes to epigenetic control of INK4a/ARF by oncogenic RAS. Genes Dev 23: $1177-1182$.

Barrett A, Madsen B, Copier J, Lu PJ, Cooper L, Scibetta AG, Burchell J, Taylor-Papadimitriou J. 2002. PLU-1 nuclear protein, which is upregulated in breast cancer, shows restricted expression in normal human adult tissues: A new cancer/testis antigen? Int $J$ Cancer 101: $581-588$.

Benevolenskaya EV, Murray HL, Branton P, Young RA, Kaelin WG Jr. 2005. Binding of pRB to the PHD protein RBP2 promotes cellular differentiation. Mol Cell 18: 623-635.

Bernstein BE, Mikkelsen TS, Xie X, Kamal M, Huebert DJ, Cuff J, Fry B, Meissner A, Wernig M, Plath K, et al. 2006. A bivalent chromatin structure marks key developmental genes in embryonic stem cells. Cell 125: 315-326.

Berra E, Benizri E, Ginouves A, Volmat V, Roux D, Pouyssegur J. 2003. HIF prolyl-hydroxylase 2 is the key oxygen sensor setting low steady-state levels of HIF-1 $\alpha$ in normoxia. EMBO J 22: 4082-4090.

Beyer S, Kristensen MM, Jensen KS, Johansen JV, Staller P. 2008. The histone demethylases JMJD1A and JMJD2B are transcriptional targets of hypoxia-inducible factor HIF. $J$ Biol Chem 283: 36542-36552.

Bishop T, Gallagher D, Pascual A, Lygate CA, de Bono JP, Nicholls LG, Ortega-Saenz P, Oster H, Wijeyekoon B, Sutherland AI, et al. 2008. Abnormal sympathoadrenal development and systemic hypotension in $\mathrm{PHD}^{-/-}$mice. Mol Cell Biol 28: 3386-3400.

Blouw B, Song H, Tihan T, Bosze J, Ferrara N, Gerber HP, Johnson RS, Bergers G. 2003. The hypoxic response of tumors is dependent on their microenvironment. Cancer Cell 4: $133-146$.

Brugarolas J, Kaelin WG Jr. 2004. Dysregulation of HIF and VEGF is a unifying feature of the familial hamartoma syndromes. Cancer Cell 6: 7-10.

Brugarolas JB, Vazquez F, Reddy A, Sellers WR, Kaelin WG Jr. 2003. TSC2 regulates VEGF through mTOR-dependent and -independent pathways. Cancer Cell 4: 147-158.

Carmeliet P, Dor Y, Herbert JM, Fukumura D, Brusselmans K, Dewerchin M, Neeman M, Bono F, Abramovitch R, Maxwell $\mathrm{P}$, et al. 1998. Role of HIF-1 $\alpha$ in hypoxia-mediated apoptosis, cell proliferation and tumour angiogenesis. Nature 394: 485-490.

Catchpole S, Spencer-Dene B, Hall D, Santangelo S, Rosewell I, Guenatri M, Beatson R, Scibetta AG, Burchell JM, TaylorPapadimitriou J. 2011. PLU-1/JARID1B/KDM5B is required for embryonic survival and contributes to cell proliferation in the mammary gland and in $\mathrm{ER}^{+}$breast cancer cells. Int J Oncol 38: 1267-1277.

Cervera AM, Bayley JP, Devilee P, McCreath KJ. 2009. Inhibition of succinate dehydrogenase dysregulates histone modification in mammalian cells. Mol Cancer 8: 89 .

Chapman MA, Lawrence MS, Keats JJ, Cibulskis K, Sougnez C, Schinzel AC, Harview CL, Brunet JP, Ahmann GJ, Adli M, et al. 2011. Initial genome sequencing and analysis of multiple myeloma. Nature 471: 467-472.

Chowdhury R, Yeoh KK, Tian YM, Hillringhaus L, Bagg EA, Rose NR, Leung IK, Li XS, Woon EC, Yang M, et al. 2011. The oncometabolite 2-hydroxyglutarate inhibits histone lysine demethylases. EMBO Rep 12: 463-469.

Christensen J, Agger K, Cloos PA, Pasini D, Rose S, Sennels L, Rappsilber J, Hansen KH, Salcini AE, Helin K. 2007. RBP2 belongs to a family of demethylases, specific for tri- and dimethylated lysine 4 on histone 3. Cell 128: 1063-1076.

Christofk HR, Vander Heiden MG, Harris MH, Ramanathan A, Gerszten RE, Wei R, Fleming MD, Schreiber SL, Cantley LC. 2008. The M2 splice isoform of pyruvate kinase is important for cancer metabolism and tumour growth. Nature 452: $230-233$.

Clifford S, Cockman M, Smallwood A, Mole D, Woodward E, Maxwell P, Ratcliffe P, Maher E. 2001. Contrasting effects on HIF- $1 \alpha$ regulation by disease-causing pVHL mutations correlate with patterns of tumourigenesis in von Hippel-Lindau disease. Hum Mol Genet 10: 1029-1038.

Cloos PA, Christensen J, Agger K, Maiolica A, Rappsilber J, Antal T, Hansen KH, Helin K. 2006. The putative oncogene GASC1 demethylates tri- and dimethylated lysine 9 on histone H3. Nature 442: 307-311.

Covello KL, Simon MC, Keith B. 2005. Targeted replacement of hypoxia-inducible factor- $1 \alpha$ by a hypoxia-inducible factor$2 \alpha$ knock-in allele promotes tumor growth. Cancer Res 65: 2277-2286.

Dahia PL, Ross KN, Wright ME, Hayashida CY, Santagata S, Barontini M, Kung AL, Sanso G, Powers JF, Tischler AS, et al. 2005. A HIF1 $\alpha$ regulatory loop links hypoxia and mitochondrial signals in pheochromocytomas. PLoS Genet 1: $72-80$.

Dalgliesh GL, Furge K, Greenman C, Chen L, Bignell G, Butler A, Davies H, Edkins S, Hardy C, Latimer C, et al. 2010. Systematic sequencing of renal carcinoma reveals inactivation of histone modifying genes. Nature 463: 360-363.

Dang CV. 2007. The interplay between MYC and HIF in the Warburg effect. Ernst Schering Found Symp Proc 4: 35-53.

Dang CV. 2010. Rethinking the Warburg effect with Myc micromanaging glutamine metabolism. Cancer Res 70: 859-862.

Dang CV, Le A, Gao P. 2009a. MYC-induced cancer cell energy metabolism and therapeutic opportunities. Clin Cancer Res 15: 6479-6483.

Dang L, White DW, Gross S, Bennett BD, Bittinger MA, Driggers EM, Fantin VR, Jang HG, Jin S, Keenan MC, et al. 2009b. Cancer-associated IDH1 mutations produce 2hydroxyglutarate. Nature 462: 739-744.

Dechant G. 2002. Chat in the trophic web: NGF activates Ret by inter-RTK signaling. Neuron 33: $156-158$.

Deckwerth TL, Johnson EM Jr. 1993. Temporal analysis of events associated with programmed cell death (apoptosis) of sympathetic neurons deprived of nerve growth factor. $J$ Cell Biol 123: $1207-1222$.

Defeo-Jones D, Huang PS, Jones RE, Haskell KM, Vuuocolo GA, Hanobik MG, Huber HE, Oliff A. 1991. Cloning of cDNAs for cellular proteins that bind to the retinoblastoma gene product. Nature 352: 251-254.

Deppmann CD, Mihalas S, Sharma N, Lonze BE, Niebur E, Ginty DD. 2008. A model for neuronal competition during development. Science 320: 369-373.

Dey BK, Stalker L, Schnerch A, Bhatia M, Taylor-Papidimitriou J, Wynder C. 2008. The histone demethylase KDM5b/JARID1b plays a role in cell fate decisions by blocking terminal differentiation. Mol Cell Biol 28: 5312-5327.

Ebert BL, Bunn HF. 1998. Regulation of transcription by hypoxia requires a multiprotein complex that includes hypoxiainducible factor 1 , an adjacent transcription factor, and p300/CREB binding protein. Mol Cell Biol 18: 4089-4096.

Erler JT, Bennewith KL, Nicolau M, Dornhofer N, Kong C, Le QT, Chi JT, Jeffrey SS, Giaccia AJ. 2006. Lysyl oxidase is essential for hypoxia-induced metastasis. Nature 440: $1222-1226$.

Erler JT, Bennewith KL, Cox TR, Lang G, Bird D, Koong A, Le QT, Giaccia AJ. 2009. Hypoxia-induced lysyl oxidase is a critical mediator of bone marrow cell recruitment to form the premetastatic niche. Cancer Cell 15: 35-44.

Fattaey A, Helin K, Dembski M, Dyson N, Harlow E, Vuocolo G, Hanobik M, Haskell K, Oliff A, Defeo-Jones D, et al. 1993. Characterization of the retinoblastoma binding proteins RBP1 and RBP2. Oncogene 8: 3149-3156.

Feng Z, Levine AJ. 2010. The regulation of energy metabolism and the IGF- $1 / \mathrm{mTOR}$ pathways by the $\mathrm{p} 53$ protein. Trends Cell Biol 20: 427-434.

Ficz G, Branco MR, Seisenberger S, Santos F, Krueger F, Hore TA, Marques CJ, Andrews S, Reik W. 2011. Dynamic regulation of 5-hydroxymethylcytosine in mouse ES cells and during differentiation. Nature 473: 398-402.

Figueroa ME, Abdel-Wahab O, Lu C, Ward PS, Patel J, Shih A, Li Y, Bhagwat N, Vasanthakumar A, Fernandez HF, et al. 
2010. Leukemic IDH1 and IDH2 mutations result in a hypermethylation phenotype, disrupt TET2 function, and impair hematopoietic differentiation. Cancer Cell 18: 553-567.

Frei C, Edgar BA. 2004. Drosophila cyclin D/Cdk4 requires Hif-1 prolyl hydroxylase to drive cell growth. Dev Cell 6: 241-251.

Gan Q, Yoshida T, McDonald OG, Owens GK. 2007. Concise review: Epigenetic mechanisms contribute to pluripotency and cell lineage determination of embryonic stem cells. Stem Cells 25: 2-9.

Gimenez-Roqueplo AP, Favier J, Rustin P, Mourad JJ, Plouin PF, Corvol P, Rotig A, Jeunemaitre X. 2001. The R22X mutation of the SDHD gene in hereditary paraganglioma abolishes the enzymatic activity of complex II in the mitochondrial respiratory chain and activates the hypoxia pathway. Am J Hum Genet 69: 1186-1197.

Gordan JD, Lal P, Dondeti VR, Letrero R, Parekh KN, Oquendo CE, Greenberg RA, Flaherty KT, Rathmell WK, Keith B, et al. 2008. HIF- $\alpha$ effects on c-Myc distinguish two subtypes of sporadic VHL-deficient clear cell renal carcinoma. Cancer Cell 14: 435-446.

Hayakawa T, Ohtani Y, Hayakawa N, Shinmyozu K, Saito M, Ishikawa F, Nakayama J. 2007. RBP2 is an MRG15 complex component and down-regulates intragenic histone $\mathrm{H} 3$ lysine 4 methylation. Genes Cells 12: 811-826.

Hayami S, Yoshimatsu M, Veerakumarasivam A, Unoki M, Iwai Y, Tsunoda T, Field HI, Kelly JD, Neal DE, Yamaue H, et al. 2010. Overexpression of the JmjC histone demethylase KDM5B in human carcinogenesis: Involvement in the proliferation of cancer cells through the E2F/RB pathway. Mol Cancer 9: 59.

He J, Kallin EM, Tsukada Y, Zhang Y. 2008. The H3K36 demethylase $\mathrm{Jhdm} 1 \mathrm{~b} / \mathrm{Kdm} 2 \mathrm{~b}$ regulates cell proliferation and senescence through p15(Ink4b). Nat Struct Mol Biol 15: $1169-1175$.

He J, Nguyen AT, Zhang Y. 2011. KDM2b/JHDM1b, an H3K36me2-specific demethylase, is required for initiation and maintenance of acute myeloid leukemia. Blood 117: 3869-3880.

Herz HM, Madden LD, Chen Z, Bolduc C, Buff E, Gupta R, Davuluri R, Shilatifard A, Hariharan IK, Bergmann A. 2010. The H3K27me3 demethylase dUTX is a suppressor of Notch- and Rb-dependent tumors in Drosophila. Mol Cell Biol 30: 2485-2497.

Hirsila M, Koivunen P, Gunzler V, Kivirikko KI, Myllyharju J. 2003. Characterization of the human prolyl 4-hydroxylases that modify the hypoxia-inducible factor. J Biol Chem 278: 30772-30780.

Hoffman M, Ohh M, Yang H, Klco J, Ivan M, Kaelin WJ. 2001. von Hippel-Lindau protein mutants linked to type $2 \mathrm{C}$ VHL disease preserve the ability to downregulate HIF. Hum Mol Genet 10: 1019-1027.

Hudson CC, Liu M, Chiang GG, Otterness DM, Loomis DC, Kaper F, Giaccia AJ, Abraham RT. 2002. Regulation of hypoxia-inducible factor $1 \alpha$ expression and function by the mammalian target of rapamycin. Mol Cell Biol 22: 7004-7014.

Isaacs JS, Jung YJ, Mole DR, Lee S, Torres-Cabala C, Chung YL, Merino M, Trepel J, Zbar B, Toro J, et al. 2005. HIF overexpression correlates with biallelic loss of fumarate hydratase in renal cancer: Novel role of fumarate in regulation of HIF stability. Cancer Cell 8: 143-153.

Ivan M, Haberberger T, Gervasi DC, Michelson KS, Gunzler V, Kondo K, Yang H, Sorokina I, Conaway RC, Conaway JW, et al. 2002. Biochemical purification and pharmacological inhibition of a mammalian prolyl hydroxylase acting on hypoxia-inducible factor. Proc Natl Acad Sci 99: 13459-13464.

Iwase S, Lan F, Bayliss P, de la Torre-Ubieta L, Huarte M, Qi HH, Whetstine JR, Bonni A, Roberts TM, Shi Y. 2007. The $\mathrm{X}$-linked mental retardation gene SMCX/JARID1C defines a family of histone $\mathrm{H} 3$ lysine 4 demethylases. Cell 128: 1077-1088.

Kaelin WG. 2002. Molecular basis of the VHL hereditary cancer syndrome. Nat Rev Cancer 2: 673-682.
Kaelin WG Jr. 2005. ROS: Really involved in oxygen sensing. Cell Metab 1: 357-358.

Kaelin WG Jr. 2007. The von Hippel-Lindau tumor suppressor protein: An update. Methods Enzymol 435: 371-383.

Kaelin WG Jr. 2009. SDH5 mutations and familial paraganglioma: Somewhere Warburg is smiling. Cancer Cell 16: $180-182$.

Kaelin WG Jr, Ratcliffe PJ. 2008. Oxygen sensing by metazoans: The central role of the HIF hydroxylase pathway. Mol Cell 30: 393-402.

Kaelin WG Jr, Thompson CB. 2010. Q\&A: Cancer: Clues from cell metabolism. Nature 465: 562-564.

Kawazu M, Saso K, Tong KI, McQuire T, Goto K, Son DO, Wakeham A, Miyagishi M, Mak TW, Okada H. 2011. Histone demethylase JMJD2B functions as a co-factor of estrogen receptor in breast cancer proliferation and mammary gland development. PLoS One 6: e17830.

Kim JW, Tchernyshyov I, Semenza GL, Dang CV. 2006 a. HIF-1-mediated expression of pyruvate dehydrogenase kinase: A metabolic switch required for cellular adaptation to hypoxia. Cell Metab 3: 177-185.

Kim WY, Safran M, Buckley MR, Ebert BL, Glickman J, Bosenberg M, Regan M, Kaelin WG Jr. 2006b. Failure to prolyl hydroxylate hypoxia-inducible factor $\alpha$ phenocopies VHL inactivation in vivo. EMBO J 25: 4650-4662.

Klose RJ, Kallin EM, Zhang Y. 2006. JmjC-domain-containing proteins and histone demethylation. Nat Rev Genet 7: $715-727$.

Klose RJ, Yan Q, Tothova Z, Yamane K, Erdjument-Bromage H, Tempst P, Gilliland DG, Zhang Y, Kaelin WG Jr. 2007. The retinoblastoma binding protein RBP2 is an H3K4 demethylase. Cell 128: 889-900.

Ko SY, Kang HY, Lee HS, Han SY, Hong SH. 2006. Identification of Jmjd1a as a STAT3 downstream gene in mES cells. Cell Struct Funct 31: 53-62.

Koivunen P, Hirsila M, Remes AM, Hassinen IE, Kivirikko KI, Myllyharju J. 2007. Inhibition of hypoxia-inducible factor (HIF) hydroxylases by citric acid cycle intermediates: Possible links between cell metabolism and stabilization of HIF. $J$ Biol Chem 282: 4524-4532.

Kondo K, Klco J, Nakamura E, Lechpammer M, Kaelin WG. 2002. Inhibition of HIF is necessary for tumor suppression by the von Hippel-Lindau protein. Cancer Cell 1: 237-246.

Kondo K, Kim WY, Lechpammer M, Kaelin WG Jr. 2003. Inhibition of HIF $\alpha$ is sufficient to suppress pVHL-defective tumor growth. PLoS Biol 1: 439-444.

Krieg AJ, Rankin EB, Chan D, Razorenova O, Fernandez S, Giaccia AJ. 2010. Regulation of the histone demethylase JMJD1A by hypoxia-inducible factor $1 \alpha$ enhances hypoxic gene expression and tumor growth. Mol Cell Biol 30: 344353.

Lee S, Nakamura E, Yang H, Wei W, Linggi MS, Sajan MP, Farese RV, Freeman RS, Carter BD, Kaelin WG Jr, et al. 2005. Neuronal apoptosis linked to EgIN3 prolyl hydroxylase and familial pheochromocytoma genes: Developmental culling and cancer. Cancer Cell 8: 155-167.

Li L, Zhang L, Zhang X, Yan Q, Minamishima YA, Olumi AF, Mao M, Bartz S, Kaelin WG Jr . 2007. Hypoxia-inducible factor linked to differential kidney cancer risk seen with type 2A and type 2B VHL mutations. Mol Cell Biol 27: 5381-5392.

Lin W, Cao J, Liu J, Beshiri M, Fujiwara Y, Francis J, Cherniack A, Geisen C, Blair L, Zou M, et al. 2011. Loss of the RBP2 histone demethylase suppresses tumorigenesis in mice lacking Rb1 or Men1. Proc Natl Acad Sci 108: 13379-13386.

Lipscomb E, Sarmiere P, Crowder R, Freeman R. 1999. Expression of the SM-20 gene promotes death in nerve growth factor-dependent sympathetic neurons. $J$ Neurochem 73: 429-432.

Liu G, Bollig-Fischer A, Kreike B, van de Vijver MJ, Abrams J, Ethier SP, Yang ZQ. 2009. Genomic amplification and oncogenic properties of the GASC1 histone demethylase gene in breast cancer. Oncogene 28: 4491-4500. 
Loh YH, Zhang W, Chen X, George J, Ng HH. 2007. Jmjd1a and Jmjd2c histone H3 Lys 9 demethylases regulate self-renewal in embryonic stem cells. Genes Dev 21: 2545-2557.

MacKenzie ED, Selak MA, Tennant DA, Payne LJ, Crosby S, Frederiksen CM, Watson DG, Gottlieb E. 2007. Cellpermeating $\alpha$-ketoglutarate derivatives alleviate pseudohypoxia in succinate dehydrogenase-deficient cells. Mol Cell Biol 27: 3282-3289.

Maranchie JK, Vasselli JR, Riss J, Bonifacino JS, Linehan WM, Klausner RD. 2002. The contribution of VHL substrate binding and HIF $1-\alpha$ to the phenotype of VHL loss in renal cell carcinoma. Cancer Cell 1: 247-255.

Marxsen JH, Stengel P, Doege K, Heikkinen P, Jokilehto T, Wagner T, Jelkmann W, Jaakkola P, Metzen E. 2004. Hypoxia-inducible factor-1 (HIF-1) promotes its degradation by induction of HIF- $\alpha$-prolyl-4-hydroxylases. Biochem $J$ 381: $761-767$.

Matoba S, Kang JG, Patino WD, Wragg A, Boehm M, Gavrilova O, Hurley PJ, Bunz F, Hwang PM. 2006. p53 regulates mitochondrial respiration. Science 312: 1650-1653.

Maxwell P, Dachs G, Gleadle J, Nicholls L, Harris A, Stratford I, Hankinson O, Pugh C, Ratcliffe P. 1997. Hypoxia-inducible factor-1 modulates gene expression in solid tumors and influences both angiogenesis and tumor growth. Proc Natl Acad Sci 94: 8104-8109.

Maxwell P, Weisner M, Chang G-W, Clifford S, Vaux E, Pugh C, Maher E, Ratcliffe P. 1999. The von Hippel-Lindau gene product is necessary for oxgyen-dependent proteolysis of hypoxia-inducible factor $\alpha$ subunits. Nature 399: 271-275.

Mazumdar J, Hickey MM, Pant DK, Durham AC, SweetCordero A, Vachani A, Jacks T, Chodosh LA, Kissil JL, Simon MC, et al. 2010. HIF-2 $\alpha$ deletion promotes Krasdriven lung tumor development. Proc Natl Acad Sci 107: $14182-14187$

Mazzone M, Dettori D, Leite de Oliveira R, Loges S, Schmidt T, Jonckx B, Tian YM, Lanahan AA, Pollard P, Ruiz de Almodovar C, et al. 2009. Heterozygous deficiency of PHD2 restores tumor oxygenation and inhibits metastasis via endothelial normalization. Cell 136: 839-851.

Minamishima YA, Moslehi J, Padera RF, Bronson RT, Liao R, Kaelin WG Jr. 2009. A feedback loop involving the Phd3 prolyl hydroxylase tunes the mammalian hypoxic response in vivo. Mol Cell Biol 29: 5729-5741.

Mole DR, Schlemminger I, McNeill LA, Hewitson KS, Pugh CW, Ratcliffe PJ, Schofield CJ. 2003. 2-oxoglutarate analogue inhibitors of HIF prolyl hydroxylase. Bioorg Med Chem Lett 13: 2677-2680.

Morris MR, Hughes DJ, Tian YM, Ricketts CJ, Lau KW, Gentle D, Shuib S, Serrano-Fernandez P, Lubinski J, Wiesener MS, et al. 2009. Mutation analysis of hypoxia-inducible factors HIF1A and HIF2A in renal cell carcinoma. Anticancer Res 29: $4337-4343$

Munirajan AK, Ando K, Mukai A, Takahashi M, Suenaga Y, Ohira M, Koda T, Hirota T, Ozaki T, Nakagawara A. 2008. KIF1B $\beta$ functions as a haploinsufficient tumor suppressor gene mapped to chromosome $1 \mathrm{p} 36.2$ by inducing apoptotic cell death. J Biol Chem 283: 24426-24434.

Nakamura E, Kaelin WG Jr. 2006. Recent insights into the molecular pathogenesis of pheochromocytoma and paraganglioma. Endocr Pathol 17: 97-106.

Northcott PA, Nakahara Y, Wu X, Feuk L, Ellison DW, Croul S, Mack S, Kongkham PN, Peacock J, Dubuc A, et al. 2009. Multiple recurrent genetic events converge on control of histone lysine methylation in medulloblastoma. Nat Genet 41: $465-472$.

Noushmehr H, Weisenberger DJ, Diefes K, Phillips HS, Pujara K, Berman BP, Pan F, Pelloski CE, Sulman EP, Bhat KP, et al. 2010. Identification of a $\mathrm{CpG}$ island methylator phenotype that defines a distinct subgroup of glioma. Cancer Cell 17: $510-522$.

Ohm JE, McGarvey KM, Yu X, Cheng L, Schuebel KE, Cope L, Mohammad HP, Chen W, Daniel VC, Yu W, et al. 2007. A stem cell-like chromatin pattern may predispose tumor suppressor genes to DNA hypermethylation and heritable silencing. Nat Genet 39: 237-242.

Papandreou I, Cairns RA, Fontana L, Lim AL, Denko NC. 2006. HIF-1 mediates adaptation to hypoxia by actively downregulating mitochondrial oxygen consumption. Cell Metab 3: 187-197.

Perez de Heredia F, Wood IS, Trayhurn P. 2010. Hypoxia stimulates lactate release and modulates monocarboxylate transporter (MCT1, MCT2, and MCT4) expression in human adipocytes. Pflugers Arch 459: 509-518.

Pfau R, Tzatsos A, Kampranis SC, Serebrennikova OB, Bear SE, Tsichlis PN. 2008. Members of a family of JmjC domaincontaining oncoproteins immortalize embryonic fibroblasts via a JmjC domain-dependent process. Proc Natl Acad Sci 105: $1907-1912$.

Pollard PJ, Briere JJ, Alam NA, Barwell J, Barclay E, Wortham NC, Hunt T, Mitchell M, Olpin S, Moat SJ, et al. 2005. Accumulation of Krebs cycle intermediates and over-expression of HIF $1 \alpha$ in tumours which result from germline FH and SDH mutations. Hum Mol Genet 14: 2231-2239.

Pollard PJ, Spencer-Dene B, Shukla D, Howarth K, Nye E, El-Bahrawy M, Deheragoda M, Joannou M, McDonald S, Martin A, et al. 2007. Targeted inactivation of fh1 causes proliferative renal cyst development and activation of the hypoxia pathway. Cancer Cell 11: 311-319.

Pollard P, Loenarz C, Mole D, McDonough M, Gleadle J, Schofield C, Ratcliffe P. 2008. Regulation of Jumonji-domaincontaining histone demethylases by hypoxia-inducible factor (HIF)-1 $\alpha$. Biochem J 416: 387-394.

Purdue MP, Johansson M, Zelenika D, Toro JR, Scelo G, Moore LE, Prokhortchouk E, Wu X, Kiemeney LA, Gaborieau V, et al. 2011. Genome-wide association study of renal cell carcinoma identifies two susceptibility loci on $2 \mathrm{p} 21$ and 11q13.3. Nat Genet 43: 60-65.

Rankin EB, Biju MP, Liu Q, Unger TL, Rha J, Johnson RS, Simon MC, Keith B, Haase VH. 2007. Hypoxia-inducible factor-2 (HIF-2) regulates hepatic erythropoietin in vivo. J Clin Invest 117: 1068-1077.

Rankin EB, Rha J, Unger TL, Wu CH, Shutt HP, Johnson RS, Simon MC, Keith B, Haase VH. 2008. Hypoxia-inducible factor-2 regulates vascular tumorigenesis in mice. Oncogene 27: $5354-5358$

Rankin EB, Rha J, Selak MA, Unger TL, Keith B, Liu Q, Haase VH. 2009. HIF-2 regulates hepatic lipid metabolism. Mol Cell Biol 29: 4527-4538.

Raval RR, Lau KW, Tran MG, Sowter HM, Mandriota SJ, Li JL, Pugh CW, Maxwell PH, Harris AL, Ratcliffe PJ. 2005. Contrasting properties of hypoxia-inducible factor 1 (HIF-1) and HIF-2 in von Hippel-Lindau-associated renal cell carcinoma. Mol Cell Biol 25: 5675-5686.

Roesch A, Fukunaga-Kalabis M, Schmidt EC, Zabierowski SE, Brafford PA, Vultur A, Basu D, Gimotty P, Vogt T, Herlyn M. 2010. A temporarily distinct subpopulation of slow-cycling melanoma cells is required for continuous tumor growth. Cell 141: 583-594.

Roy PG, Thompson AM. 2006. Cyclin D1 and breast cancer. Breast 15: 718-727.

Rui L, Emre NC, Kruhlak MJ, Chung HJ, Steidl C, Slack G, Wright GW, Lenz G, Ngo VN, Shaffer AL, et al. 2010. Cooperative epigenetic modulation by cancer amplicon genes. Cancer Cell 18: 590-605.

Ryan H, Lo J, Johnson R. 1998. HIF-1 $\alpha$ is required for solid tumor formation and embryonic vascularization. EMBO 17: 3005-3015.

Safran M, Kim WY, O’Connell F, Flippin L, Gunzler V, Horner JW, Depinho RA, Kaelin WG Jr. 2006. Mouse model for noninvasive imaging of HIF prolyl hydroxylase activity: Assessment of an oral agent that stimulates erythropoietin production. Proc Natl Acad Sci 103: 105-110.

Sar A, Ponjevic D, Nguyen M, Box AH, Demetrick DJ. 2009. Identification and characterization of demethylase JMJD1A as a gene upregulated in the human cellular response to hypoxia. Cell Tissue Res 337: 223-234. 
Schietke R, Warnecke C, Wacker I, Schodel J, Mole DR, Campean V, Amann K, Goppelt-Struebe M, Behrens J, Eckardt KU, et al. 2010. The lysyl oxidases LOX and LOXL2 are necessary and sufficient to repress E-cadherin in hypoxia: Insights into cellular transformation processes mediated by HIF-1. J Biol Chem 285: 6658-6669.

Schlemminger I, Mole DR, McNeill LA, Dhanda A, Hewitson KS, Tian YM, Ratcliffe PJ, Pugh CW, Schofield CJ. 2003. Analogues of dealanylalahopcin are inhibitors of human HIF prolyl hydroxylases. Bioorg Med Chem Lett 13: 1451-1454.

Schlisio S, Kenchappa RS, Vredeveld LC, George RE, Stewart R, Greulich H, Shahriari K, Nguyen NV, Pigny P, Dahia PL, et al. 2008. The kinesin KIF1B $\beta$ acts downstream from EglN3 to induce apoptosis and is a potential 1p36 tumor suppressor. Genes Dev 22: 884-893.

Seagroves T, Ryan H, Lu H, Wouters B, Knapp M, Thibault P, Laderoute K, Johnson R. 2001. Transcription factor HIF-1 is a necessary mediator of the pasteur effect in mammalian cells. Mol Cell Biol 21: 3463-3444.

Secombe J, Li L, Carlos L, Eisenman RN. 2007. The Trithorax group protein Lid is a trimethyl histone $\mathrm{H} 3 \mathrm{~K} 4$ demethylase required for dMyc-induced cell growth. Genes Dev 21: 537-551.

Selak MA, Armour SM, Mackenzie ED, Boulahbel H, Watson DG, Mansfield KD, Pan Y, Simon MC, Thompson CB, Gottlieb E. 2005. Succinate links TCA cycle dysfunction to oncogenesis by inhibiting HIF- $\alpha$ prolyl hydroxylase. Cancer Cell 7: 77-85.

Selak MA, Duran RV, Gottlieb E. 2006. Redox stress is not essential for the pseudo-hypoxic phenotype of succinate dehydrogenase deficient cells. Biochim Biophys Acta 1757: $567-572$.

Sellers WR, Kaelin WG. 1997. Role of the retinoblastoma protein in the pathogenesis of human cancer. J Clin Onc 15: $3301-3312$.

Semenza GL. 2003. Targeting HIF-1 for cancer therapy. Nat Rev Cancer 3: 721-732.

Seth P, Krop I, Porter D, Polyak K. 2002. Novel estrogen and tamoxifen induced genes identified by SAGE (Serial Analysis of Gene Expression). Oncogene 21: 836-843.

Shen C, Beroukhim R, Schumacher SE, Zhou J, Chang M, Signoretti S, Kaelin WG. 2011. Genetic and functional studies implicate HIF $1 \alpha$ as a $14 q$ kidney cancer suppressor gene. Cancer Discovery 1: 222-235.

Shi L, Sun L, Li Q, Liang J, Yu W, Yi X, Yang X, Li Y, Han X, Zhang Y, et al. 2011. Histone demethylase JMJD2B coordinates $\mathrm{H} 3 \mathrm{~K} 4 / \mathrm{H} 3 \mathrm{~K} 9$ methylation and promotes hormonally responsive breast carcinogenesis. Proc Natl Acad Sci 108: $7541-7546$.

Smith EH, Janknecht R, Maher LJ 3rd. 2007. Succinate inhibition of $\alpha$-ketoglutarate-dependent enzymes in a yeast model of paraganglioma. Hum Mol Genet 16: 3136-3148.

Steeg PS, Zhou Q. 1998. Cyclins and breast cancer. Breast Cancer Res Treat 52: 17-28.

Stiehl DP, Wirthner R, Koditz J, Spielmann P, Camenisch G, Wenger RH. 2006. Increased prolyl 4-hydroxylase domain proteins compensate for decreased oxygen levels. Evidence for an autoregulatory oxygen-sensing system. J Biol Chem 281: $23482-23491$.

Straub JA, Lipscomb EA, Yoshida ES, Freeman RS. 2003. Induction of SM-20 in PC12 cells leads to increased cytochrome c levels, accumulation of cytochrome $\mathrm{c}$ in the cytosol, and caspase-dependent cell death. J Neurochem 85: $318-328$.

Sudarshan S, Sourbier C, Kong HS, Block K, Valera Romero VA, Yang Y, Galindo C, Mollapour M, Scroggins B, Goode N, et al. 2009. Fumarate hydratase deficiency in renal cancer induces glycolytic addiction and hypoxia-inducible transcription factor $1 \alpha$ stabilization by glucose-dependent generation of reactive oxygen species. Mol Cell Biol 29: 4080-4090.

Sudarshan S, Shanmugasundaram K, Naylor SL, Lin S, Livi CB, O’Neill CF, Parekh DJ, Yeh IT, Sun LZ, Block K. 2011.
Reduced expression of fumarate hydratase in clear cell renal cancer mediates HIF- $2 \alpha$ accumulation and promotes migration and invasion. PLoS One 6: e21037.

Tzatsos A, Pfau R, Kampranis SC, Tsichlis PN. 2009. Ndy1/ KDM2B immortalizes mouse embryonic fibroblasts by repressing the Ink4a/Arf locus. Proc Natl Acad Sci 106: 2641-2646.

Ullah MS, Davies AJ, Halestrap AP. 2006. The plasma membrane lactate transporter MCT4, but not MCT1, is up-regulated by hypoxia through a HIF-1 $\alpha$-dependent mechanism. J Biol Chem 281: 9030-9037.

van Haaften G, Dalgliesh GL, Davies H, Chen L, Bignell G, Greenman C, Edkins S, Hardy C, O'Meara S, Teague J, et al. 2009. Somatic mutations of the histone H3K27 demethylase gene UTX in human cancer. Nat Genet 41: $521-523$.

Vogel KS, Brannan CI, Jenkins NA, Copeland NG, Parada LF. 1995. Loss of neurofibromin results in neurotrophin-independent survival of embryonic sensory and sympathetic neurons. Cell 82: 733-742.

Wang JK, Tsai MC, Poulin G, Adler AS, Chen S, Liu H, Shi Y, Chang HY. 2010. The histone demethylase UTX enables RB-dependent cell fate control. Genes Dev 24: 327-332.

Wellmann S, Bettkober M, Zelmer A, Seeger K, Faigle M, Eltzschig HK, Buhrer C. 2008. Hypoxia upregulates the histone demethylase JMJD1A via HIF-1. Biochem Biophys Res Commun 372: $892-897$.

Wissmann M, Yin N, Muller JM, Greschik H, Fodor BD, Jenuwein T, Vogler C, Schneider R, Gunther T, Buettner R, et al. 2007. Cooperative demethylation by JMJD2C and LSD1 promotes androgen receptor-dependent gene expression. Nat Cell Biol 9: 347-353.

Xia X, Lemieux ME, Li W, Carroll JS, Brown M, Liu XS, Kung AL. 2009. Integrative analysis of HIF binding and transactivation reveals its role in maintaining histone methylation homeostasis. Proc Natl Acad Sci 106: 4260-4265.

Xu W, Yang H, Liu Y, Yang Y, Wang P, Kim SH, Ito S, Yang C, Xiao MT, Liu LX, et al. 2011. Oncometabolite 2-hydroxyglutarate is a competitive inhibitor of $\alpha$-ketoglutarate-dependent dioxygenases. Cancer Cell 19: 17-30.

Yamada D, Kobayashi S, Yamamoto H, Tomimaru Y, Noda T, Uemura M, Wada H, Marubashi S, Eguchi H, Tanemura M, et al. 2011. Role of the hypoxia-related gene, JMJD1A, in hepatocellular carcinoma: clinical impact on recurrence after hepatic resection. Ann Surg Oncol doi: 10.1245/s10434-0111797-x.

Yamane K, Tateishi K, Klose RJ, Fang J, Fabrizio LA, Erdjument-Bromage H, Taylor-Papadimitriou J, Tempst P, Zhang Y. 2007. PLU-1 is an H3K4 demethylase involved in transcriptional repression and breast cancer cell proliferation. Mol Cell 25: 801-812.

Yang ZQ, Imoto I, Fukuda Y, Pimkhaokham A, Shimada Y, Imamura M, Sugano S, Nakamura Y, Inazawa J. 2000. Identification of a novel gene, GASC1, within an amplicon at 9p23-24 frequently detected in esophageal cancer cell lines. Cancer Res 60: 4735-4739.

Yang ZQ, Imoto I, Pimkhaokham A, Shimada Y, Sasaki K, Oka M, Inazawa J. 2001. A novel amplicon at 9p23-24 in squamous cell carcinoma of the esophagus that lies proximal to GASC1 and harbors NFIB. Jpn J Cancer Res 92: 423-428.

Yang J, Jubb AM, Pike L, Buffa FM, Turley H, Baban D, Leek R, Gatter KC, Ragoussis J, Harris AL. 2010. The histone demethylase JMJD2B is regulated by estrogen receptor $\alpha$ and hypoxia, and is a key mediator of estrogen induced growth. Cancer Res 70: 6456-6466.

Yeh IT, Lenci RE, Qin Y, Buddavarapu K, Ligon AH, Leteurtre E, Do Cao C, Cardot-Bauters C, Pigny P, Dahia PL. 2008. A germline mutation of the KIF1B $\beta$ gene on $1 \mathrm{p} 36$ in a family with neural and nonneural tumors. Hum Genet 124: 279-285.

Yeung SJ, Pan J, Lee MH. 2008. Roles of p53, MYC and HIF-1 in regulating glycolysis-The seventh hallmark of cancer. Cell Mol Life Sci 65: 3981-3999. 
Yoshimi A, Kurokawa M. 2011. Key roles of histone methyltransferase and demethylase in leukemogenesis. J Cell Biochem 112: 415-424.

Zhang Q, Gu J, Li L, Liu J, Luo B, Cheung HW, Boehm JS, Ni M, Geisen C, Root DE, et al. 2009. Control of cyclin D1 and breast tumorigenesis by the EgIN2 prolyl hydroxylase. Cancer Cell 16: 413-424.
Zhao S, Lin Y, Xu W, Jiang W, Zha Z, Wang P, Yu W, Li Z, Gong L, Peng Y, et al. 2009. Glioma-derived mutations in IDH1 dominantly inhibit IDH1 catalytic activity and induce HIF-1 $\alpha$. Science 324: 261-265.

Zimmer M, Doucette D, Siddiqui N, Iliopoulos O. 2004. Inhibition of hypoxia-inducible factor is sufficient for growth suppression of $\mathrm{VHL}^{-/-}$tumors. Mol Cancer Res 2: 89-95. 


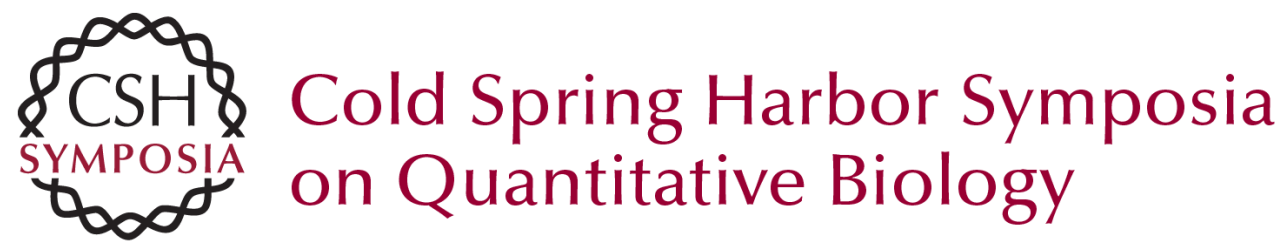

\title{
Cancer and Altered Metabolism: Potential Importance of Hypoxia-Inducible Factor and 2-Oxoglutarate-Dependent Dioxygenases
}

\author{
W.G. Kaelin, Jr.
}

Cold Spring Harb Symp Quant Biol 2011 76: 335-345 originally published online November 16, 2011

Access the most recent version at doi:10.1101/sqb.2011.76.010975

$\begin{array}{ll}\text { References } & \begin{array}{l}\text { This article cites } 150 \text { articles, } 52 \text { of which can be accessed free at: } \\ \text { http://symposium.cshlp.org/content/76/335.full.html\#ref-list-1 }\end{array}\end{array}$

\section{License}

Email Alerting
Service $\quad \begin{aligned} & \text { Receive free email alerts when new articles cite this article - sign up in } \\ & \text { the box at the top right corner of the article or click here. }\end{aligned}$

To subscribe to Cold Spring Harbor Symposia on Quantitative Biology go to: http://symposium.cshlp.org/subscriptions 